Helgoländer wiss. Meeresunters. 17, 291-301 (1968)

\title{
Some effects of pollution on the benthic environment of the Gullmarsfjord
}

\author{
ERKKI LEPPÄKOSKI \\ Kristineberg Zoological Station, Fiskebäckskil, Sweden
}

\begin{abstract}
KURZFASSUNG: Einige Einflüsse der Verunreinigung auf das Benthos des Gullmarsfjords. Der Saltkällefjord, ein Arm des Gullmarsfjords an der Westküste Schwedens, wird seit mehr als achtzig Jahren von den Abwässern einer Sulfitzellulose- und Papierfabrik beeinflußt. Um die Einflüsse der Verunreinigung verfolgen zu können, sind hydrographische und biologische Untersuchungen von der Zoologischen Station Kristineberg durchgeführt worden. Das Ziel dieser Arbeit ist die Beschreibung des heutigen Zustandes der Sedimente und der Bodenfauna im Saltkällefjord. Bei den hydrographischen und bodenfaunistischen Untersuchungen wurden konventionelle Methoden benutzt. Die Sedimentproben - mit einem Schlammstecher gewonnen - entstammen den oberen $8 \mathrm{~cm}$ des Sedimentes. Sie wurden in $2 \mathrm{~cm}$ didke Sektionen geschnitten und zentrifugiert, wobei das interstitielle Wasser abgetrennt wurde. Im interstitiellen Wasser wurde ein relativ hoher und im Sediment abwärts zunehmender Salzgehalt festgestellt. Um die Beschaffenheit der verunreinigten Böden im Saltkällefjord zu charakterisieren, sind die großen Glühverluste der Sedimente, die Sauerstoffarmut des Bodenwassers, das beträchtliche Volumen, die hohe $\mathrm{KMnO}_{4}-\mathrm{Zahl}$, der relativ niedrige $\mathrm{pH}$-Wert und das häufige Auftreten von Schwefelwasserstoff im interstitiellen Wasser zu berücksichtigen. Außerhalb der Mündung des Flusses Ơrekilsälven ist die Bodenfauna vollständig verschwunden. An der Außenseite dieses unbewohnten Gebietes ist eine Grenzzone, charakterisiert durch das Vorkommen des Polychaeten Capitella capitata, zu finden. Im mittleren Teil des Fjords sind Maxima der Individuenzahl und der Zahl der Bodentierarten festgestellt worden. Das Maximum der Individuenzahl hat sich seit 1932 etwa $2 \mathrm{~km}$ und das Maximum der Artenzahl auf $1,2 \mathrm{~km}$ in südwestlicher Richtung verlagert. Capitella capitata, eine dort erst neuerdings auftretende Species, ist bei dieser Bestandsaufnahme nicht berücksichtigt worden.
\end{abstract}

\section{INTRODUCTION}

The Gullmarsfjord on the west coast of Sweden is - in terms of its biological aspects - probably one of the best known water systems of Europe. The hydrographical situation provides excellent conditions for a rich animal life, which has made the fjord a centre of Swedish marine biological research.

In the region of the fjord threshold, municipal sewage from the preserving works and the town of Lysekil ( 7000 inhabitants) enters the fjord, and for more than 80 years one of the shallow branches of the fjord, the Saltkallefjord, has received sewage from the Munkedal paper and sulphite pulp mills.

The animal life of the Gullmarsfjord is threatened by industrial expansion in the 
region. In order to obtain data on the quantitative and qualitative occurrence of pollution in the Saltkällefjord, hydrographical and biological studies have been made since 1964, in the region concerned, by the Kristineberg Zoological Station, with the help of grants from the Swedish Natural Science Research Council. The biological studies were made primarily on the bottom fauna. The reason for this is that comparable information on the bottom fauna is available from 1923 (Molander 1928, discussed further in Molander 1962) and from 1932 (Lindroth 1935), thus providing possibilities for detecting changes in regard to composition and distribution of the bottom fauna.

The purpose of the present paper is to illustrate briefly the situation of the bottom fauna today, and to point out some environmental factors that may be important for the assessment of the degree of pollution in an estuary affected by sewage from a cellulose producing plant. A more detailed study on the bottom fauna will be published later.

The investigated region is $5 \mathrm{~km}$ long, and covers an area of $4.85 \mathrm{~km}^{2}$. The depth at the fjord threshold is 35 to $40 \mathrm{~m}$. Immediately inside the threshold is a deeper basin $(66 \mathrm{~m})$, otherwise the depth of the fjord decreases rather evenly. The central parts of the fjord are 30 to $40 \mathrm{~m}$ deep. Hitherto the greatest source of pollution has been a sulphite cellulose and paper mill on the river Orekilsälven, about $5 \mathrm{~km} \mathrm{NNE} \mathrm{of} \mathrm{the}$ Saltkällefjord. Cessation of manufacturing sulphite pulp at this plant in 1966 has created a greater need for mapping possible recolonization phenomena in the fauna of the polluted parts of the fjord.

\section{METHODS}

Only salinity and oxygen contents of the bottom water layers are reported here. Salinity and temperature were measured by a portable salinity-temperature bridge (N.I.O.). Oxygen content was determined according to the Winkler method (STRICKLAND \& PARSONS 1965); the degree of saturation in per cent was calculated according to the tables in Truesdale, Downing \& Lowden (1955).

In order to make a preliminary assessment of some parameters in the sediment and interstitial water, sediment cores were taken with a core sampler $\left(15 \mathrm{~cm}^{2}\right)$. These cores were analyzed in sections of $2 \mathrm{~cm}$ thickness $(30 \mathrm{ml}$ volume) to $8 \mathrm{~cm}$ below the sediment surface. The calcination loss was measured on stove- dried $\left(105^{\circ} \mathrm{C}\right)$ material by combustion for 30 minutes at $850^{\circ} \mathrm{C}$.

In other sediment samples, oxygen content and salinity were determined immediately above the surface of the sediment. Interstitial water was extracted in a refrigerated centrifuge (International PR-2; $0^{\circ} \mathrm{C}, 2000$ r.p.m., 20 minutes). The volume, $\mathrm{pH}$ (Radiometer 22), salinity (against Standard Sea-water) and $\mathrm{KMnO}_{4}$ consumption (according to Deutsches Einheitsverfahren zur Wasseruntersuchung 1960; applied for water samples of $25 \mathrm{ml}$; boiling in an alkaline solution) were determined for the water extracted from each section.

A mechanically homogenized sample of sediment gave the following results in 10 successive analyses: salinity $32.70 \pm 0.01 \%$; volume $636 \pm 5,2 \mathrm{ml} / 1$ sediment; 
$\mathrm{pH} 7.9 \pm 0.0$, and $\mathrm{KMnO}_{4}$ consumption $66.8 \pm 2.8 \mathrm{mg} / \mathrm{l}$; determinations of salinity, volume and $\mathrm{pH}$, seem to have a reliability sufficient for ecological purposes. The greatest source of error in determining $\mathrm{KMnO}_{4}$ was probably the great dilution with distilled water, which is necessary when small amounts of water are to be analyzed.

The bottom fauna was studied during the periods September and October, 1966, and May and June, 1967, with conventional methods: Petersen grab $0.1 \mathrm{~m}^{2} ; 2$ or 3 samples per station, mesh size $1 \mathrm{~mm}$. The material was sorted in the laboratory and the animals were weighed alive, i.e., no correction coefficient was used in the calculation of biomass values. The stations were localized by photographed landmarks.

Table 1

Salinity near the bottom at some stations during October 1964 to May 1967

\begin{tabular}{|cccccc|}
\hline Station & $\begin{array}{c}\text { Number of } \\
\text { observations }\end{array}$ & min. & max. & $\begin{array}{c}\text { Salinity (\%o) } \\
\text { mean }\end{array}$ & $\begin{array}{c}\text { Standard } \\
\text { deviation }\end{array}$ \\
\hline 3 & 17 & 19.95 & 32.95 & 26.55 & 2.99 \\
6 & 18 & 28.60 & 33.50 & 31.27 & 1.52 \\
9 & 7 & 30.75 & 33.55 & 32.69 & 1.11 \\
10 & 10 & 27.60 & 33.10 & 31.25 & 1.48 \\
12 & 23 & 30.10 & 33.85 & 32.24 & 0.88 \\
18 & 7 & 31.80 & 33.90 & 32.64 & 0.70 \\
20 & 25 & 32.15 & 34.75 & 33.38 & \\
\hline
\end{tabular}

Table 2

Dissolved oxygen near the bottom during October 1964 to May 1967

\begin{tabular}{|cccccc|}
\hline Station & $\begin{array}{c}\text { Number of } \\
\text { observations }\end{array}$ & min. & max. & $\begin{array}{c}\text { Oxygen mg/ } \\
\text { mean }\end{array}$ & $\begin{array}{c}\text { Standard } \\
\text { deviation }\end{array}$ \\
\hline 3 & 14 & 4.2 & 13.5 & 8.6 & 2.8 \\
6 & 19 & 0.0 & 12.5 & 6.0 & 3.5 \\
9 & 8 & 5.0 & 8.4 & 6.7 & 1.1 \\
12 & 19 & 2.9 & 8.7 & 5.6 & 1.8 \\
15 & 5 & 5.0 & 9.3 & 7.0 & 2.0 \\
18 & 9 & 2.6 & 7.9 & 6.0 & 2.6 \\
20 & 22 & 0.3 & 8.3 & 4.6 & \\
\hline
\end{tabular}

\section{RESULTS}

\section{Salinity}

Characteristic of the surface layer of water in the Saltkällefjord is its great variation in salinity. At the mouth of the fjord (Station 20 ), the extreme values $1.5 \%$ and $26.1 \%$ have been observed. The depth of the $30 \%$ isohaline varies between 10 and $20 \mathrm{~m}$. The mean salinities of the bottom layers of water at some stations are 
given in Table 1. The conditions in the soft bottom region may be regarded as euhaline as far out as Station 9, located off the mouth of the river.

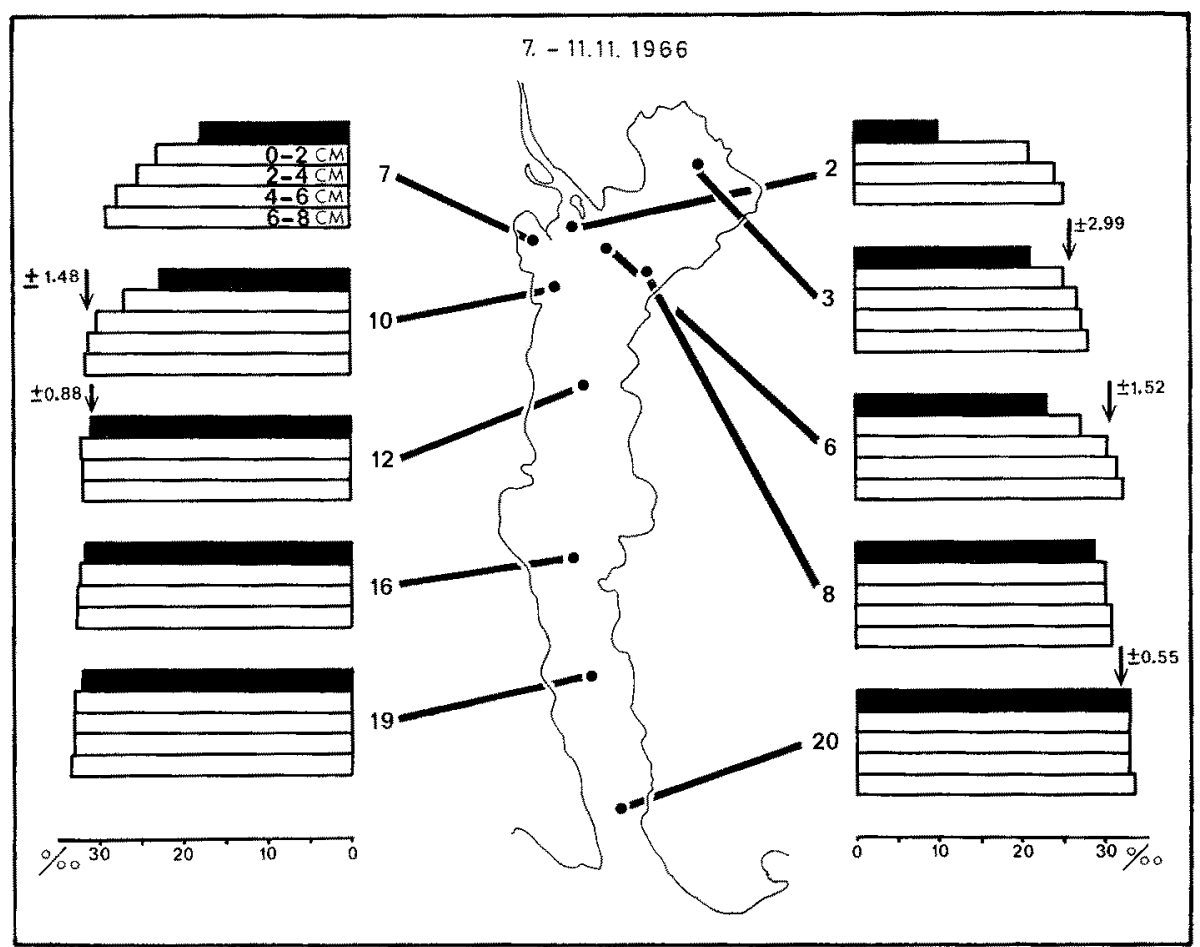

Fig. 1: Salinity in the interstitial water in sediments of the Saltkällefjord. Black columns: salinity of bottom water. White columns: salinities in upper section of the sediment. Mean salinities of bottom water are indicated by arrows and their standard deviations given for the period October 1964 to May 1967

Relatively low salinities are found in November, also close to the bottom. A survey of the salinity of the upper sections of the sediment (Fig. 1), on the other hand, shows high values during this season, too, in 1966. A successive rise in salinity from the surface of the sediment to a depth of $8 \mathrm{~cm}$ was found at all stations in the innermost parts of the fjord.

\section{Oxygen}

The results of the determinations of oxygen content of the bottom water layers are shown in Figure 2 and Table 2 in terms of (1) mean oxygen content 1964 to 67, (2) minimum value observed during this period, and (3) three longitudinal sections indicating the oxygen content of the water 0 to $10 \mathrm{~cm}$ above the surface of the sediment. According to these, the Saltkallefjord may be divided into two critical bottom regions. At the mouth of the river, where the bottom is exposed to a deposition of extraneous 
organic matter, above all wood fibre, even a total lack of oxygen has been observed in October and November. On the other hand, the deepest basin, near the mouth of the fjord, is subject to stagnation periods of varying duration and a reduction of the oxygen content in autumn.

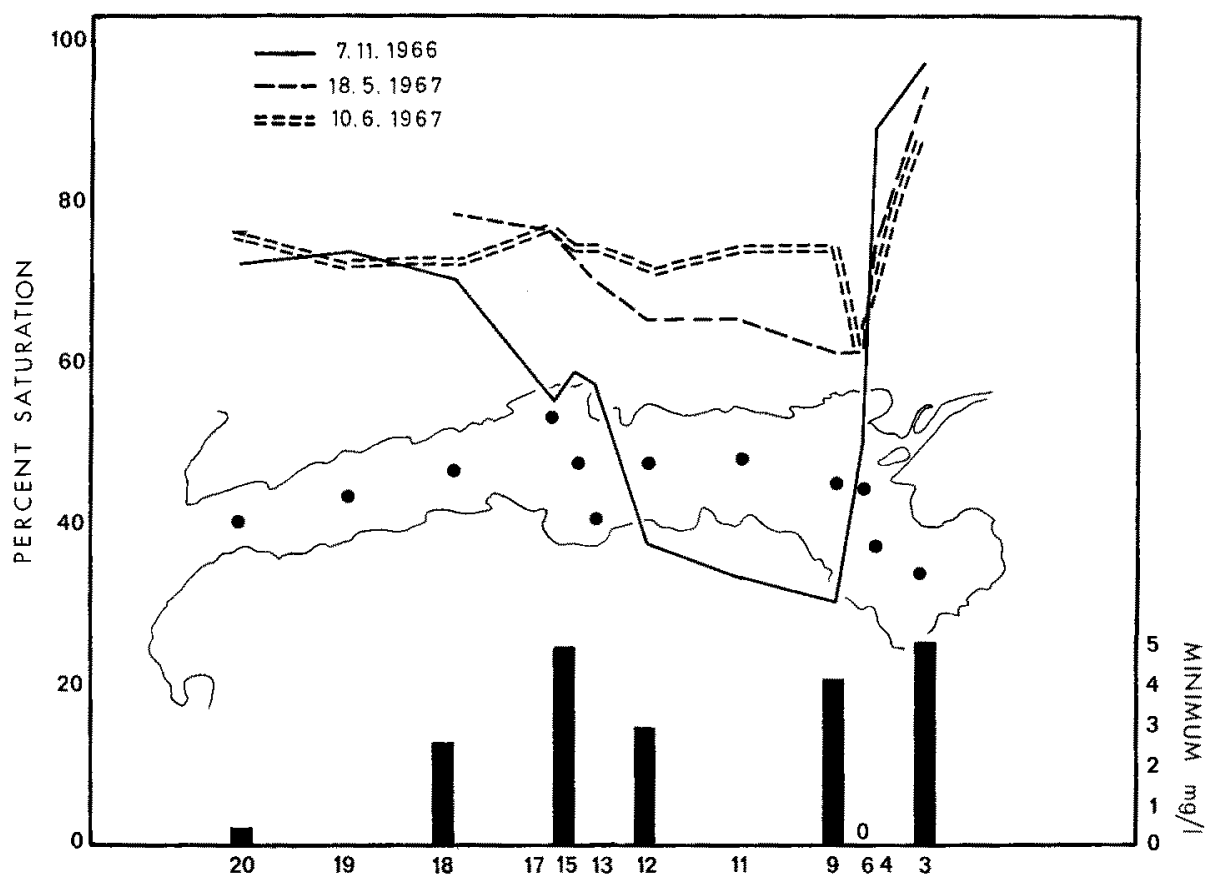

Fig. 2: Horizontal distribution of dissolved oxygen in the water overlying the sediment surface. The oxygen minimum was observed in the bottom water from October 1964 to May 1967

\section{Calcination loss}

The content of oxidizable matter in the form of percentage loss of weight caused by ignition in the sediments varies between 6.2 and 18.4 per cent (Table 3 ). The highest values are usually found in the top $2 \mathrm{~cm}$. At Stations 7 and 12, large calcination losses were found at as great a depth as $8 \mathrm{~cm}$, which was due to the wood fibre and sawdust in the sediment.

\section{$\mathrm{pH}$ of interstitial water}

The $\mathrm{pH}$ of the interstitial water varied in the region between 7.0 and 8.3 (Table 3). The only remarkable decline in the $\mathrm{pH}$ was found at the mouth of the river (Stations 2 and 7). As a rule, the $\mathrm{pH}$ rises from the mud-water interface towards the deeper layers of sediment. 
Table 3

Calcination losses in the sediments. Volume, $\mathrm{pH}$, salinity and $\mathrm{KMnO}_{4}$-consumption of the interstitial water. For the location of the stations, consult Figures 1 to 4

\begin{tabular}{|c|c|c|c|c|c|c|c|}
\hline \multirow[b]{2}{*}{ Station } & \multirow[b]{2}{*}{$\begin{array}{l}\text { Depth } \\
\text { m }\end{array}$} & \multirow[b]{2}{*}{$\begin{array}{l}\text { Depth in } \\
\text { sediment } \\
\mathrm{cm}\end{array}$} & \multirow[b]{2}{*}{$\begin{array}{l}\text { Calcination } \\
\text { loss } \\
\text { per cent }\end{array}$} & \multicolumn{3}{|c|}{ Interstitial water } & \multirow[b]{2}{*}{$\begin{array}{l}\mathrm{KMnO}_{4-}^{-} \\
\text {consumption } \\
\text { mg/l }\end{array}$} \\
\hline & & & & $\begin{array}{l}\text { Volume } \\
\text { ml/l } \\
\text { sediment }\end{array}$ & $\mathrm{pH}$ & $\begin{array}{c}\text { Salinity } \\
\% 00\end{array}$ & \\
\hline \multirow[t]{3}{*}{2} & 3 & $0-2$ & & 420 & 7.1 & 21.1 & $\left(\mathrm{H}_{2} \mathrm{~S}\right)$ \\
\hline & & $2-4$ & & 346 & 7.0 & 23.9 & $(\mathrm{H} \odot \mathrm{S})$ \\
\hline & & $4-6$ & & 360 & 7.2 & 25.2 & $\left(\mathrm{H}_{2} \mathrm{~S}\right)$ \\
\hline \multirow[t]{4}{*}{3} & 10 & $0-2$ & 11.8 & 313 & 7.7 & 25.2 & 95 \\
\hline & & $2-4$ & 10.5 & 333 & 7.7 & 26.7 & 64 \\
\hline & & 46 & 10.6 & 170 & 8.1 & 27.3 & \\
\hline & & $6-8$ & 9.3 & 137 & 8.0 & 27.6 & \\
\hline \multirow[t]{4}{*}{4} & 13 & $0-2$ & 12.6 & 226 & 7.6 & & 76 \\
\hline & & $2-4$ & 10.6 & 220 & 7.7 & & 94 \\
\hline & & $4-6$ & 10.8 & 196 & 7.9 & & \\
\hline & & $6-8$ & 10.7 & 110 & 7.9 & & \\
\hline \multirow[t]{4}{*}{5} & 19 & $0-2$ & & 306 & 7.8 & & \\
\hline & & $2-4$ & & 230 & 7.9 & & \\
\hline & & $4-6$ & & 210 & 8.0 & & \\
\hline & & $6-8$ & & 130 & 8.1 & & \\
\hline \multirow[t]{4}{*}{6} & 21 & $0-2$ & 12.8 & 506 & 7.5 & 27.4 & $\left(\mathrm{H}_{2} \mathrm{~S}\right)$ \\
\hline & & $2-4$ & 8.4 & 320 & 7.8 & 30.4 & $\left(\mathrm{H}_{2} \mathrm{~S}\right)$ \\
\hline & & $4-6$ & 7.5 & 263 & 8.0 & 31.4 & $(\mathrm{H} 2 \mathrm{~S})$ \\
\hline & & $6-8$ & & 107 & 8.0 & 31.8 & $\left(\mathrm{H}_{2} \mathrm{~S}\right)$ \\
\hline \multirow[t]{4}{*}{7} & 13 & $0-2$ & 18.4 & 336 & 7.6 & 23.1 & 57 \\
\hline & & $2-4$ & 17.3 & 476 & 7.5 & 25.3 & 108 \\
\hline & & $4-6$ & 16.8 & 350 & 7.7 & 27.6 & \\
\hline & & $6-8$ & 13.6 & 343 & 7.5 & 28.8 & \\
\hline \multirow[t]{4}{*}{8} & 20 & $0-2$ & & 323 & 7.6 & 29.8 & 48 \\
\hline & & $2-4$ & & 213 & 7.8 & 29.8 & 69 \\
\hline & & $4-6$ & & 160 & 7.9 & 30.7 & \\
\hline & & $6-8$ & & 127 & 8.0 & 30.5 & \\
\hline \multirow[t]{4}{*}{9} & 25 & $0-2$ & 10.8 & 290 & 7.7 & 31.3 & \\
\hline & & $2-4$ & 8.7 & 256 & 7.9 & 31.1 & \\
\hline & & $4-6$ & 7.4 & 213 & 7.8 & 31.1 & \\
\hline & & $6-8$ & 7.2 & 157 & 8.1 & 31.9 & \\
\hline \multirow[t]{4}{*}{10} & 22 & $0-2$ & & 433 & 8.2 & 27.0 & $\left(\mathrm{H}_{2} \mathrm{~S}\right)$ \\
\hline & & $2-4$ & & 235 & 8.2 & 30.2 & $\left(\mathrm{H}_{2} \mathrm{~S}\right)$ \\
\hline & & $4-6$ & & 240 & 8.3 & 31.4 & $\left(\mathrm{H}_{2} \mathrm{~S}\right)$ \\
\hline & & $6-8$ & & 182 & 8.3 & 31.6 & $\left(\mathrm{H}_{2} \mathrm{~S}\right)$ \\
\hline \multirow[t]{4}{*}{11} & 25 & $0-2$ & 9.0 & 220 & 7.8 & & 114 \\
\hline & & $2-\overline{4}$ & 8.2 & 203 & 7.9 & & 117 \\
\hline & & $4-6$ & 8.6 & 96 & & & \\
\hline & & 6-8 & 7.7 & 66 & & & \\
\hline \multirow[t]{4}{*}{12} & 33 & $0-2$ & 12.2 & 200 & 7.7 & 32.2 & 94 \\
\hline & & $2-4$ & 9.6 & 260 & 7.8 & 31.6 & 51 \\
\hline & & $4-6$ & 13.0 & 127 & 7.8 & 31.6 & \\
\hline & & $6-8$ & 12.4 & & & & \\
\hline \multirow[t]{4}{*}{13} & 33 & $0-2$ & 9.3 & 246 & 7.8 & 32.2 & 70 \\
\hline & & $2-4$ & 8.5 & 180 & 7.8 & 32.5 & 50 \\
\hline & & $4-6$ & 9.5 & 150 & 7.9 & 32.8 & \\
\hline & & $6-8$ & 9.3 & 200 & 8.0 & 33.4 & \\
\hline \multirow[t]{4}{*}{15} & 37 & $0-2$ & 12.9 & 360 & 7.7 & 32.2 & 30 \\
\hline & & $2-4$ & 12.0 & & & & \\
\hline & & 46 & 8.7 & & & & \\
\hline & & $6-8$ & 6.2 & & & & \\
\hline
\end{tabular}


Table 3

(continued)

\begin{tabular}{|c|c|c|c|c|c|c|c|}
\hline \multirow[b]{2}{*}{ Station } & \multirow[b]{2}{*}{$\begin{array}{l}\text { Depth } \\
\text { m }\end{array}$} & \multirow[b]{2}{*}{$\begin{array}{l}\text { Depth in } \\
\text { sediment } \\
\mathrm{cm}\end{array}$} & \multirow[b]{2}{*}{$\begin{array}{l}\text { Calcination } \\
\text { loss } \\
\text { per cent }\end{array}$} & \multicolumn{3}{|c|}{ Interstitial water } & \multirow[b]{2}{*}{$\underset{\text { mg/l }}{\mathrm{KMnO}_{4-}^{-}}$} \\
\hline & & & & $\begin{array}{l}\text { Volume } \\
\mathrm{m} 1 / 1 \\
\text { sediment }\end{array}$ & $\mathrm{pH}$ & $\underset{\% \%}{\text { Salinity }}$ & \\
\hline \multirow[t]{4}{*}{16} & 37 & $0-2$ & & 240 & 7.8 & 32.3 & 24 \\
\hline & & $2-4$ & & 202 & 8.0 & 32.6 & 30 \\
\hline & & 46 & & 150 & 8.0 & 32.3 & \\
\hline & & $6-8$ & & 30 & 8.0 & & \\
\hline \multirow[t]{4}{*}{17} & 37 & $0-2$ & & 310 & 7.6 & & 47 \\
\hline & & $2-4$ & & 230 & 7.6 & & 64 \\
\hline & & $4-6$ & & 190 & 7.9 & & \\
\hline & & $6-8$ & & 127 & 7.9 & & \\
\hline \multirow{4}{*}{19} & 56 & $0-2$ & 10.8 & 320 & 7.5 & 32.8 & 75 \\
\hline & & $2-4$ & 10.3 & 213 & 7.6 & 32.8 & \\
\hline & & $4-6$ & 10.3 & 157 & 7.7 & 32.8 & \\
\hline & & $6-8$ & 9.8 & 90 & 8.0 & 33.1 & \\
\hline \multirow[t]{4}{*}{20} & 66 & $0-2$ & 10.7 & 320 & 7.6 & 32.8 & \\
\hline & & $2-4$ & 10.3 & 180 & 7.8 & 32.8 & 77 \\
\hline & & $4-6$ & 9.8 & 133 & 7.9 & 32.8 & \\
\hline & & $6-8$ & 9.5 & 47 & 8.0 & 33.4 & \\
\hline
\end{tabular}

\section{Interstitial water}

The volume of interstitial water which can be separated by centrifuging was calculated as $\mathrm{ml} /$ litre sediment (Fig. 3, Table 3). A distinct rise in the values was observed at the river mouth, particularly on the northwestern side of the fjord. Apart from the bottoms rich in wood fibre, the volume of interstitial water declines regularly downward to the depth of $8 \mathrm{~cm}$.

\section{$\mathrm{KMnO}_{4}$ consumption}

The $\mathrm{KMnO}_{4}$ values were determined only in sections 0 to 2 and 2 to $4 \mathrm{~cm}$ of the sediment cores (Table 3). An approximate mean of these values is shown in Figure 3. The presence of hydrogen sulphide makes $\mathrm{KMnO}_{4}$ titration in the samples from the river mouth impossible. Outside this region, a reduction in the values was observed towards the south and southwest. The $\mathrm{KMnO}_{4}$ consumption of the interstitial water varies between 24 and $117 \mathrm{mg} / \mathrm{l}$.

\section{The bottom fauna}

The results of the study of the bottom fauna have been condensed in a map (Fig. 4) as abundance, biomass and number of species. A longitudinal section from the 


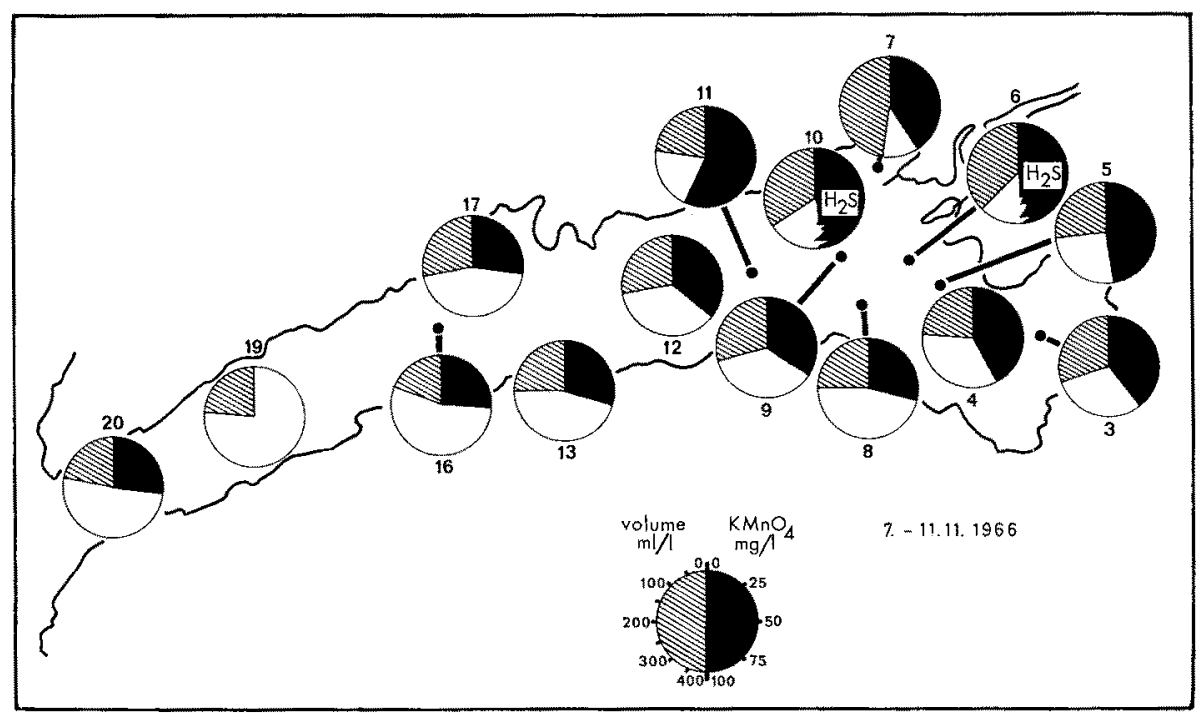

Fig. 3: Volume (ruled) and $\mathrm{KMnO}_{4}$ consumption (black) of the interstitial water

innermost inlet of the fjord to the mouth of the fjord shows clearly that the bottom fauna outside the river mouth has totally disappeared. In the bay east of the river mouth, only a few species of Polychaeta (Nephtbys bombergi, Nereis diversicolor, Scolelepis fuliginosa, etc.) and Mollusca (Corbula gibba, Pbiline aperta) were found.

The boundary region adjacent to the unpopulated area is dominated by the polychaete Capitella capitata (Stations 4, 11, 12). The greatest abundance of Capitella (5160 individuals $/ \mathrm{m}^{2}$ ) was found at Station 11.

Half way up the fjord, a distinct maximum can be observed in the numerical occurrence of bottom fauna. The three most abundant species (Amphiura filiformis, Montacuta ferruginosa and Thyasira flexwosa) account for more than 72 per cent of the number of individuals in this region (Stations 13, 15, 17). Two species, Brissopsis lyrifera and Ampbiura fliformis, dominated the biomass, of which they comprised 70 per cent at these three stations.

Both biomass and abundance decline towards the mouth of the fjord, and at Station 20 an impoverished bottom fauna was found, consisting of a few polychaetes (e. g. Polyphysia crassa, Heteromastus filiformis and Maldane sarsi) and bivalves (Thyasira Rexuosa and Corbula gibba).

The number of benthic species shows a clear coincidence with the biomass and abundance, although a maximum was found at Station 18 , outside the most densely populated region.

Data on the bottom fauna from the stations most comparable in position with LINDROTH's (1935) stations in 1932, are collected in Table 4. The values from LindROTH's work were taken from a diagram and are therefore only approximate. According to my results, the maximum density of the bottom fauna has, since Lindrotr's study was made, moved from Station 9 to Station 15 , that is, about $2 \mathrm{~km}$ to the 


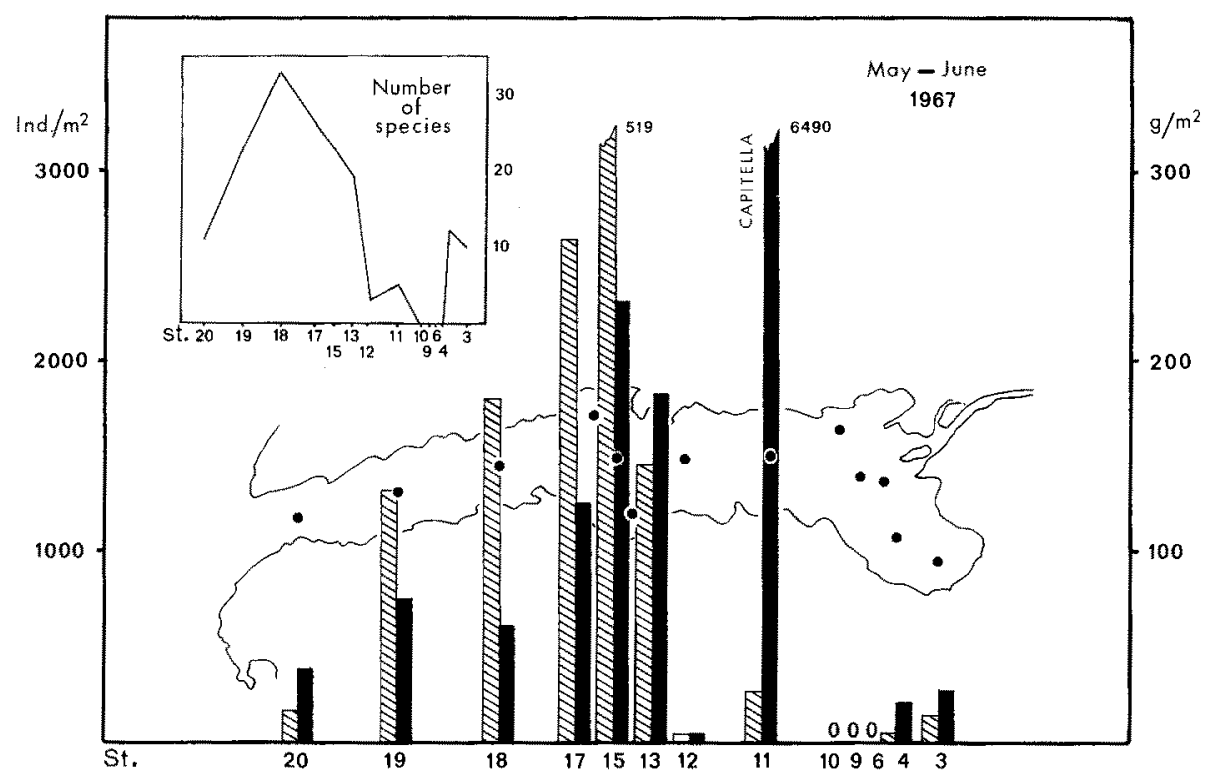

Fig. 4: Horizontal distribution of the bottom fauna (May to June 1967). Number of individuals (black), wet biomass (ruled) and number of species (inset)

southwest in the fjord. The occurrence of Capitella was not reported by LINDROTH. This species may probably be regarded as a new component in the fauna of the Saltkallefjord and is not, therefore, directly comparable in this connection. The maximum of the number of species has moved from Station 14 (1932) to Station 18 (1967). The distance between these stations is about $1.2 \mathrm{~km}$. The most radical change has taken place at Station 9, outside the river mouth, where Lindrotr's 27 species have disappeared completely.

Table 4

Numerical occurrence of the bottom fauna at some of the stations in 1932 (LINDroth 1935) and 1966 to 1967

\begin{tabular}{|rcrrrrrrr|}
\hline Station & $\begin{array}{c}\text { Station in } \\
\text { LindRoTH }\end{array}$ & \multicolumn{3}{c}{ Number of species } & \multicolumn{3}{c|}{ Number of specimens/m } \\
& 1935 & 1932 & 1966 & 1967 & 1932 & 1966 & 1967 \\
\hline 3 & 16 & 11 & 10 & 13 & 170 & 300 & 270 \\
5 & 15 & 15 & 10 & & 350 & 1200 & \\
9 & 11 & 27 & 0 & 0 & 850 & 0 & 0 \\
14 & 9 & 31 & 25 & & 620 & 1200 & \\
16 & 8 & 22 & 24 & & 320 & 1200 & \\
18 & 6 & 25 & 34 & 33 & 300 & 790 & 605 \\
20 & 5 & 23 & & 11 & 280 & & 380 \\
\hline
\end{tabular}




\section{DISCUSSION}

The salinity of the interstitial water in littoral sand and intertidal sediments has often been discussed. As far as the populated surface layers of soft bottom sediments are concerned, SANDERs et al. (1965) demonstrated the stability of salinity $4 \mathrm{~cm}$ deep in the sediment, and the significance of sediment salinities for the distribution of the sediment-penetrating marine species in an estuary affected by tides.

My preliminary results confirm this. The tides in the Saltkällefjord are insignificant. Because of the high salinity values both in the bottom water and in the interstitial water, salinity cannot be regarded as a limiting factor of great importance for the distribution of the marine benthic species in the Saltkällefjord.

Compared with the other parts of the fjord, the sediment at the mouth of the river Orekilsälven is characterized by the great contents of interstitial water and organic matter (expressed as $\mathrm{KMnO}_{4}$ consumption and calcination loss), somewhat lower $\mathrm{pH}$ values, small oxygen contents, the presence of $\mathrm{H}_{2} \mathrm{~S}$ and the absence of macroscopic bottom animals. These coinciding factors, and also the presence of wood fibre and sawmill waste in the sediment, tend to be more obvious at the stations near the NW shore of the fjord. This is most likely a consequence of the topography, the dominant SW winds and the rotation of the earth.

Most bottom invertebrates live more in than on the sediment. In so far as the undeniable indicator value of the quantities of bottom fauna in cases of pollution can be accepted, certain phenomena in the interstitial environment must be described in greater detail. A standardization of suitable methods belonging to the sphere of interest of biology seems necessary.

\section{SUMMARY}

1. In the Gullmarsfjord (west coast of Sweden), an area affected by paper- and pulpmill wastes was studied.

2. In the interstitial water separated by centrifuging, a relatively high salinity was found. In the studied topmost $8 \mathrm{~cm}$ of the sediment, the salinity increased distinctly downward.

3. The polluted sediments, containing wood fibre, had high calcination losses and great contents of interstitial water. This water had a low $\mathrm{pH}$ and great $\mathrm{KMnO}_{4}$ consumption.

4. Disappearance of the bottom fauna on the most heavily polluted area and the moving of the maxima of the faunal parameters during a period of 35 years are demonstrated.

Acknowledgements: To Dr. B. Swedmarx, Chief of the Kristineberg Zoological Station, I extend my sincere thanks for his constant help. I also wish to thank the skippers on "Sven Lovén". Mr. P. BAGGE, mag. phil., has made the hydrographical observations 1964 to 1965. Dr. A. Eliason kindly identified the Polychaeta. This study has been supported by the Swedish Natural Science Research Council. 


\section{LITERATURE CITED}

Linoroth, A., 1935. Die Assoziationen der marinen Weichböden. Zool. Bidr. 15, 331-368.

Molander, A. R., 1928: Animal communities on soft bottom areas in the Gullmar fjord. (Kristinebergs Zoologiska Station 1877-1927.) SkrSer. K. svenska VetenskAkad. 1928 (2), $1-90$.

- 1962. Studies of the fauna in the fjords of Bohuslän with reference to the distribution of different associations. Ark. Zool. (Ser. 2) 15, 1-64.

Sanders, H. L., Mangelsdorf, P. C. \& Hampson, G. R., 1965. Salinity and faunal distribution in the Pocasset River, Massachusetts. Limnol. Oceanogr. 10 (Suppl.), 216-229.

Strickiand, J. D. H. \& Parsons, T. R., 1965. A manual of sea water analysis. 2nd ed. Bull. Fish. Res. Bd Can. 125, 1-203.

Truesdale, G. A., Downing, A. L. \& Lowden, G. F., 1955. The solubility of oxygen in pure water and sea water. J. appl. Chem. 5, 53-62.

\section{Discussion following the paper by LEPPÄKOSKI}

LÜNEBURG: Ich habe die gleiche Zunahme des Salzgehalts im Tonsediment des Gullmarfjords festgestellt wie Sie, also etwa $2 \%$ gegenüber dem freien Wasser. Haben Sie eine Vorstellung über die Ursache dieser Zunahme? Ist das Interstitialwasser eventuell subfossil?

Leppäroskr: Thank you for this information. This question of sediment salinities is very difficult for me to answer as a biologist, but I hope that the theory of ionic adsorption on the sediment grains is valid also today. 